\title{
Revisión
}

\section{El virus influenza y la gripe aviar}

\section{(Influenza virus and avian flu)}

\author{
Libia Herrero-Uribe
}

\section{Resumen}

En este artículo se presenta una revisión del virus influenza, su biología, sus mecanismos de variación antigénica, las pandemias que ha producido y la prevención mediante las vacunas y medicamentos antivirales. Se analizan las razones por las cuales aparece el virus H5N1 que produce la fiebre aviar en humanos, la patogénesis de este virus y las estrategias para su prevención. Se informa sobre el plan de preparación para la pandemia en los niveles nacional e internacional.

Descriptores: Influenza A, gripe aviar, pandemia, H5N1

\begin{abstract}
This article presents a review of Influenza virus, its biology, its mechanism of antigenic variation and its prevention by vaccination and the use of antivirals. The pandemics produced by this virus through history are presented. The appearance of the avian flu virus $\mathrm{H} 5 \mathrm{~N} 1$ is analyzed and its pathogenesis and strategies of prevention are discussed. National and international information about pandemic preparedness is presented.
\end{abstract}

Key words: Influenza A, avian influenza, pandemia, HN1

Recibido: 13 de setiembre de 2007

Aceptado: 16 de octubre de 2007

Sección de Virología, Centro de InvestigacionesenEnfermedades Tropicales (CIET), Facultad de Microbiología, Universidad de Costa Rica.

Correspondencia: e-mail Iherrero@cariari.ucr.ac.cr

ISSN 0001-6002/2008/50/1/13-19 Acta Médica Costarricense, (C2008 Colegio de Médicos y Cirujanos

\section{La gripe y el virus de la influenza $A$}

La gripe se considera una enfermedad emergente, por la capacidad que tiene el virus de influenza A, de variar antigénicamente sus glicoproteínas externas y burlar así la inmunidad adquirida por la población. Esto obedece fundamentalmente a que su ácido nucleico es un ARN segmentado, el cual codifica por una ARN polimerasa que no tiene función de corregir los errores de lectura y, por lo tanto, se produce una alta tasa de mutaciones. El genoma está dividido en 8 segmentos con capacidad de codificar para 10 proteínas virales. Esta característica muy especial le permite que dos virus diferentes puedan multiplicarse en la misma célula y se mezclen los segmentos de ARN, dando lugar a variantes con diferente virulencia para una especie dada . ${ }^{1}$

El virus influenza se clasifica en los tipos A, B y C, según las características antigénicas de dos de sus proteínas internas (M y NP), y en subtipos, según las características antigénicas de sus dos glicoproteínas: la hemaglutinina y la neuraminidasa. Los tipos $\mathrm{B}$ y $\mathrm{C}$ solo infectan a los humanos, pero el tipo A afecta a varias especies: los humanos, los cerdos, los caballos, las aves de corral, las ballenas, los lobos de mar y otras. Los diferentes subtipos y variantes son especieespecíficos, es decir, en general atacan a una sola especie y produciendo enfermedad respiratoria. ${ }^{2}$ Las aves silvestres y migratorias son los hospederos naturales que albergan todos los subtipos de 
virus influenza A sin causarles daño aparente y excretan los virus por medio de las heces. ${ }^{3}$

El virus influenza A codifica 10 proteínas, dos de las cuales son glicoproteínas que se proyectan a través de la membrana fosfolipídica de la partícula viral: la hemaglutinina $(\mathrm{H})$ y la neuraminidasa $(\mathrm{N})$. La proteína $\mathrm{M} 1$ es la que le da la estructura a la partícula y la M2 es un canal de protones que sirve para acidificar el virus con el fin de que pueda desnudarse de su cápside y liberar los segmentos de ribonucleoproteína (RNP) para que vayan al núcleo celular y sean replicados. Posee, además, tres proteínas ligadas a la RNP que tienen su función en la transcripción y la replicación del ácido nucleico viral. También contiene dos proteínas no estructurales responsables del proceso de replicación inicial. $^{2}$

La hemaglutinina $(\mathrm{H})$ es la que reconoce los residuos de ácido siálico en la membrana celular y son los receptores para que el virus pueda hacer el primer contacto con la célula e iniciar la infección; además, es responsable de la penetración del virus, de su patogenicidad y de su virulencia. $\mathrm{La} \mathrm{H}$ es una glicoproteína muy inmunogénica, y anticuerpos específicos contra ella neutralizan el virus completamente, ya que interfieren con el reconocimiento de los receptores en el nivel celular que son residuos de ácido siálico. ${ }^{4} \mathrm{La}$ neuraminidasa $(\mathrm{N})$ es una enzima que elimina residuos de ácido siálico de la membrana celular y tiene la función de liberar el virus de las células, y los anticuerpos también son importantes en el control de la infección. Estas dos glicoproteínas son las que más sufren de variación antigénica, ya que los anticuerpos producidos contra las variantes anteriores no son tan específicos ni ávidos para las nuevas, por lo tanto, son menos protectores. ${ }^{2}$

Existen 16 tipos de hemaglutininas y 9 tipos de neuraminidasas; sus mezclas pueden ofrecer un total de 144 posibilidades más todas sus variantes, debido a la variación antigénica. Los virus humanos poseen las combinaciones de $\mathrm{H} 1, \mathrm{H} 2, \mathrm{H} 3$ y N1 y N2, las cuales se comparten con los cerdos. Los virus que circulan en las aves de corral son: H5, $\mathrm{H} 6, \mathrm{H} 7, \mathrm{H} 9$ y N1, N2, N3, N7, las ballenas y gaviotas tienen H13, N2, N6 y todos los tipos, subtipos y variantes se encuentran en las aves migratorias y silvestres. ${ }^{3,5}$

Existen dos clases de variación antigénica, la menor (drift) y la mayor (shift). La menor se produce por cambios concretos en el nivel del ácido nucleico, los cuales se traducen en cambios de aminoácidos en los sitios antigénicos de la molécula. Se ha sugerido que estos cambios ocurren por la presión inmunológica, de manera que el virus escapa a los anticuerpos específicos y puede seguir replicándose y seleccionando sus mejores características para perpetuarse. Este cambio menor se puede representar de la siguiente manera: H,H", H'", H'"'", donde cada coma es una mutación, pero se mantiene una relación antigénica entre ellas, por lo tanto, hay reconocimiento por parte de los anticuerpos, sin embargo, cuanto más alejados estén antigénicamente, habrá menos protección; ${ }^{2}$ por este motivo se deben producir vacunas todos los años. ${ }^{2,6}$

La variación mayor ocurre cuando hay un intercambio de segmentos de genomas de virus diferentes durante una infección mixta; en este caso puede aparecer un nuevo virus desconocido para el sistema inmune y de alta virulencia, lo que llevaría a la posibilidad de una pandemia. ${ }^{2}$ (Ver el recuadro A de la Figura 1.)

\section{Las pandemias del virus influenza}

Las pandemias ocurren cuando aparece una nueva glicoproteína $\mathrm{H}$ acompañada $\mathrm{o}$ no de una nueva neuraminidasa, para las cuales los humanos son negativos inmunológicamente. Esto es lo que se conoce como un cambio antigénico mayor, que ocurre por el entrecuzamiento o rearreglo entre genomas de diferentes subtipos de virus. ${ }^{2}$ La primera pandemia de gripe bien documentada, llamada "la influenza española", ocurrió en 1918 y 1919, con más de 50 millones de muertes reportadas. ${ }^{7,8}$ Esta pandemia fue producida por el subtipo H1N1, el cual se creyó que provenía del cerdo, pero hoy se sabe que ese virus se transmitió directamente de las aves a los humanos. ${ }^{9,10}$ Debido a la alta mortalidad que causó, algunos sugieren que la cepa responsable fue muy virulenta, sin embargo, otros argumentan que las infecciones secundarias bacterianas en una época sin disponibilidad de antibióticos pudieron ser uno de los motivos por los cuales hubo tanta mortalidad, además de las condiciones de vida de la población después de la Primera Guerra Mundial. Pero, los últimos estudios realizados del virus causal de esa pandemia, obtenido por la técnica de la genética reversa de cadáveres congelados, han demostrado que este fue muy virulento, ya que inducía una reacción inmunológica exacerbada y producía la muerte en pocas horas a adultos jóvenes, que fue el grupo de edad más afectado en esa ocasión. ${ }^{7,9}$

En 1957 se produce la "pandemia asiática" por el virus H2N2, donde se estimó un exeso de muertes de más de 2 millones de personas en el mundo entero, asociadas a influenza ${ }^{11}$ La pandemia de 1968 se inició en Hong Kong, por el subtipo de virus H3N2 y se estimó alrededor de un millón de muertes asociadas al virus, siendo más leve que

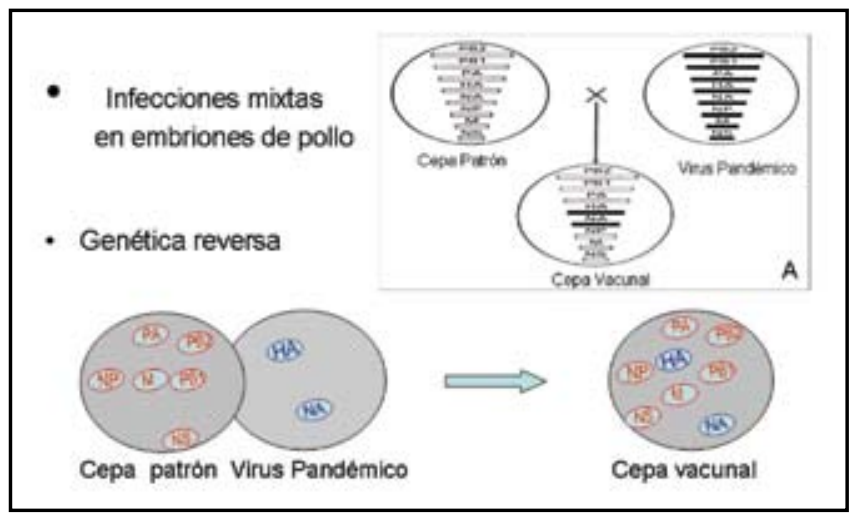

Figura 1. Producción de las Vacunas de Influenza. 
las anteriores, posiblemente por que solo cambió la hemaglutinina. ${ }^{11}$ Como se puede observar en el cuadro1, cada vez que apareció un nuevo tipo de virus pandémico en los años 1918, 1957 y 1968, el que circulaba anteriormente desaparecía de la población humana. ${ }^{12}$

En 1977 reapareció el virus H1N1, y produjo una gran preocupación entre las autoridades de salud, pues se pensó que era la misma cepa de la pandemia de 1918-19, pero luego se determinó que su aparición no fue un fenómeno natural, sino que aparentemente obedeció una negligencia humana. ${ }^{12}$ En esa oportunidad, las autoridades de salud de los Estados Unidos procedieron a la producción de grandes cantidades de vacuna que fueron aplicadas a la población de riesgo de las epidemias estacionales (mayores de 65 años). La vacuna tuvo reacciones secundarias muy graves, lo que produjo muchas muertes, a pesar de que el virus resultó ser poco virulento. En esa ocasión, como se demuestra en el Cuadro 1, ambos virus se mantuvieron entre la población humana, resultando en epidemias en menores de 20 años, grupo de edad que no había tenido contacto con el virus H1N1, ya que este desapareció en $1957 .{ }^{12}$ En 2001 apareció el virus H1N2, producto del intercambio de los dos virus circulantes en humanos, el cual no produjo brotes, ya que la mayoría de la población era inmune a ambos virus. ${ }^{13}$

Estudios filogenéticos han demostrado que el virus H2N2 de la pandemia de 1957 apareció del H1N1 circulante, que adquirió los genes $\mathrm{H} 2$, N2 y PB1 de virus de aves, y el $\mathrm{H} 3 \mathrm{~N} 2$ posiblemente provino del virus $\mathrm{H} 2 \mathrm{~N} 2$ circulante, que adquirió los genes H3 y PB1 de virus de especies aviares, ${ }^{14}$ en ambos casos, por infecciones mixtas.

\section{La gripe aviar}

Las aves silvestres son los hospederos naturales de todos los tipos, subtipos y variantes del virus influenza y, por lo tanto, la evolución de los virus es bastante estática en ellas. ${ }^{5}$ En las aves silvestres los virus se multiplican en el sistema gastrointestinal y, por eso, se eliminan en grandes cantidades por las heces. En los adultos jóvenes de algunas especies

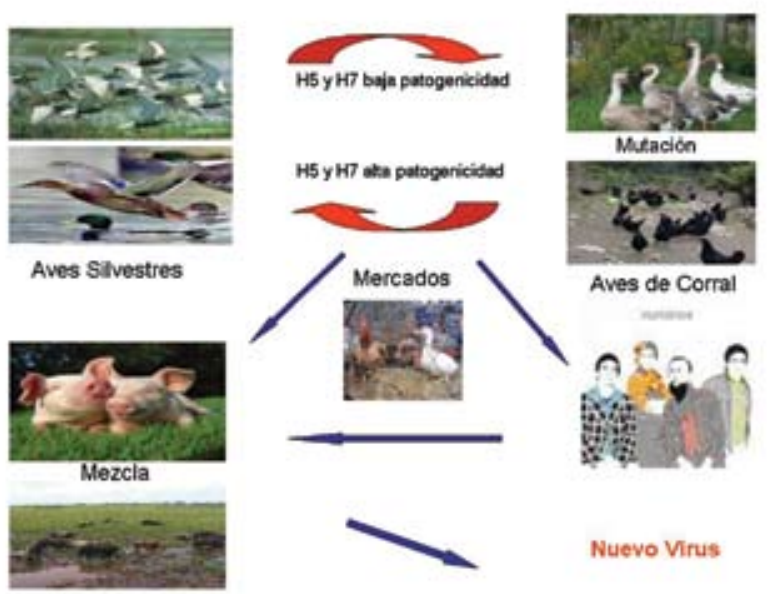

Figura 2. Evolución de los Virus Influenza.

\begin{tabular}{|llc|}
\hline \multicolumn{3}{|c|}{ Cuadro 1. Las Pandemias de Influenza } \\
\hline • Influenza española & $1918-1919$ & H1N1 \\
• Influenza asiática & 1957 & H2N2 \\
• Influenza Hong Kong & 1968 & H3N2 \\
• & 1977 & H1N1 y H3N2 \\
• & 2001 & H1N1, H3N2 y H1N2 \\
& $? ? ? ?$ & H5N1 u otra \\
\hline
\end{tabular}

pueden producir una sintomatología respiratoria muy leve. ${ }^{5}$ En algunos países asiáticos es común llevar a pastar las aves de corral a los arrozales o humedales, donde se ponen en contacto con las aves silvestres y en tal contexto ocurre el intercambio de virus. En las aves silvestres y las aves de corral circulan cepas de $\mathrm{H} 5$ que son de baja virulencia (LPAI o low pathogenic avian influenza), las cuales pueden mutar en las aves de corral, adquiriendo su alta virulencia (high pathogenic avian influenza, HPAI) produciendo brotes y muerte (Figura 2). Solo los virus con hemaglutininas H5 y $\mathrm{H} 7$ pueden evolucionar a cepas de alta virulencia lo cual ocurre en las aves de corral. El intercambio de virus se produce entonces en las áreas donde las aves intercambian tiempo, alimentos y heces en la naturaleza, y también en los mercados de las grandes ciudades donde se mantienen animales vivos de varias especies en condiciones de estrés, hambre y hacinamiento, lo que propicia el intercambio de virus y la aparición de nuevas cepas virales. ${ }^{5,15,16,21}$

Las cepas aviares de alta virulencia o cepas "fowl plague" se conocen desde 1961, por producir brotes ocasionales en aves de corral, pero desde 1994 los reportes fueron más frecuentes e importantes en diferentes países. ${ }^{17}$ En 1997, en Hong Kong, se indica por primera vez la transmisión de una cepa de alta virulencia $\mathrm{H} 5 \mathrm{~N} 1$ de aves de corral a los seres humanos. En esa ocasión ocurrió en personas que estuvieron en estrecho contacto con las aves enfermas en el mercado de esa ciudad y se reportaron 18 enfermos con un $66 \%$ de mortalidad. Para combatir el problema se tomaron las medias de contención correspondientes y se sacrificaron más de 140 millones de aves de corral.

En 2003 se reportó la aparición de una nueva cepa de H5N1 de alta virulencia, con capacidad de enfermar y causar la muerte a algunas especies de aves silvestres, situación que no había sido reportada en el pasado. Esta nueva cepa adquirió la capacidad de transmitirse al ser humano produciendo enfermedad con una mortalidad del $50 \%$, y se refieren casos y muertes en varios países asiáticos, que suscitan la alarma general sobre la posibilidad de una nueva pandemia. Antes de 1997 se creía que los virus pandémicos solo aparecían cuando un virus aviar (AI) intercambiaba genes con los virus humanos circulantes en la población, como ocurrió en 1957 y 1968. Pero en los últimos 10 años se 


\begin{tabular}{|l|}
\multicolumn{1}{|c|}{ Cuadro 2. Vías de transmisión } \\
\hline - Virus humanos \\
- Inhalación y fomites \\
- Virus aviar en humanos \\
- Inhalación y fomites \\
- Conjuntiva \\
- Se ha determinado ARN viral en sangre y en heces \\
de pacientes \\
- Es neurotrópico \\
- Inhibe el interferón y alfa - TNF \\
- Induce tormenta de citoquinas
\end{tabular}

ha reportado que los virus aviares pueden infectara humanos directamente, produciendo infecciones respiratorias leves, conjuntivitis, enfermedad respiratoria y muerte, como en el caso del H5. ${ }^{18}$

Desde el brote en Hong Kong se han realizado estudios de evolución de los virus H5 N1 y se ha demostrado que al principio los cambios fueron por intercambio genético, sin embargo, en los últimos tiempos los cambios determinados son mutaciones en la proteína PB2, inserciones en la $\mathrm{H}$ y delecciones en la N. Todos estos cambios evolutivos conllevan a adquirir la capacidad de infectar humanos, causar enfermedad neurotrópica, así como la muerte en algunas especies de aves silvestres, e infectar a felinos, ratones y hurones, con consecuencias fatales..$^{5,19}$

En el Cuadro 2 se describe la forma de transmisión de los virus humanos estacionales y el H5N1 que ha estado causando la fiebre aviar en humanos. Como se puede observar, por medio de los intercambios genéticos y las mutaciones en sus diferentes proteínas y glicoproteínas, el virus ha adquirido características que aumentan su posibilidad de infección y diseminación, además de aumentar el número de las especies que pueden actuar como hospederos. Las aves silvestres son la fuente de donde los virus pandémicos pueden surgir. Los virus aviares pueden ser introducidos en la población humana mediante un intercambio genético con virus humanos circulantes o por infección directa. ${ }^{18}$

\section{El tropismo y los receptores}

Los virus en general reconocen un receptor específico en su célula hospedera que les permite hacer el primer contacto con la célula para iniciar la infección. Las hemaglutininas de los virus de las aves reconocen residuos de ácido siálico en unión 2-3 con la galactosa en la membrana celular. Esta clase de receptores solo se encuentran en las células bronquiales no ciliadas, en las células alveolares y en la conjuntiva de los seres humanos. Las hemaglutininas de los virus humanos reconocen los residuos de ácido siálico con un enlace 2-6 con la galactosa, el cual se puede encontrar

\begin{tabular}{|ll|}
\hline \multicolumn{2}{|c|}{ Cuadro 3. Receptores y tropismo } \\
\hline - Galactosa---Ac. Siático & - Galactosa---Ac. Siático \\
2-----------3 & 2------------6 \\
Virus de aves & Virus de humanos \\
- Células bronquiales no & - Células epiteliales de la \\
ciliadas & mucosa nasal y paranasal \\
- Células alveolares & - Faringe \\
- Conjuntiva & - Tráquea \\
& - Bronquios \\
& - Bronquiolos \\
\hline
\end{tabular}

en las células epiteliales de la mucosa nasal y paranasal, en la faringe, tráquea, bronquios y bronquiolos ${ }^{4}$ (Cuadro 3).

Los casos nuevos de gripe por H5N1 en humanos, notificados últimamente, suelen aparecer en las zonas rurales de los diferentes países asiáticos, y ocurren por la exposición de la persona a una dosis muy alta de virus, que se produce a través de los aerosoles originados al sacrificar las aves enfermas sin las medidas de higiene adecuadas. Al producirse la infección directamente en el pulmón, le es más difícil al virus ser excretado e infectar a otras personas, lo que limita los riesgos. ${ }^{20}$

El epitelio respiratorio de los cerdos tiene ambos receptores, por lo tanto, pueden ser infectados por virus humanos y aviares; ya que los cerdos viven en proximidad a los humanos y a las aves, existe una preocupación constante de que esta especie sirva de agente mezclador de virus y pueda aparecer un virus nuevo con capacidad de infectar y diseminarse entre los humanos, además de ser más virulento. ${ }^{14}$

\section{¿En qué consiste la alta virulencia de este virus?}

La molécula de hemaglutinina se sintetiza como un precursor llamado Ho, el cual debe sufrir una protéolisis para que la molécula tenga un cambio conformacional y adquiera sus capacidades patogénicas. En los virus que son de virulencia baja y media (LPAI), esta proteólisis la ejecutan enzimas extracelulares que se limitan al tracto respiratorio y gastrointestinal, pero las cepas de virus más virulentas (HPAI) sufren una o varias mutaciones en el sitio donde ocurre la protéolisis, cambiando la especificidad por enzimas ubicuas que se encuentran en células de diferentes sitios anatómicos y, por lo tanto, el virus logra producir infección sistémica. ${ }^{3,15,21}$

Los sitios de la molécula de hemaglutinina que son decisivos en la virulencia del virus son: a) los sitios antigénicos, ya que al cambiar, los anticuerpos producidos por sus hospederos en una infección anterior pierden la especificidad y la avidez por las moléculas mutadas; b) el 
sitio que reconoce el receptor en el nivel celular, y c) el sitio donde ocurre la proteólisis para que exista el cambio conformacional de la molécula de Ho. ${ }^{3,15,21}$

Es importante mencionar que la constelación total de genes es lo que determinará la patogenicidad y virulencia de los virus influenza, dado que sus proteínas internas también tienen la capacidad de mutar y cambiar sus efectos sobre las células hospederas, dándole al virus características como la de multiplicarse óptimamente, inhibir la inmunidad innata, exacerbar la respuesta de citoquinas y sensibilizar la célula a la apoptosis..$^{21,22}$

\section{Prevención}

La vacuna: La vacuna contra influenza estacional contiene los tres virus circulantes en humanos: el H3N2, H1N1 y el influenza B. La variabilidad antigénica de los virus hace que se produzcan y apliquen las vacunas contra influenza todos los años. La escogencia de las cepas efectuada como vacunas se hace por medio de la vigilancia epidemiológica que se realiza alrededor del mundo, donde laboratorios especializados se dedican a aislar, cultivar e identificar los virus circulantes en la población que luego se envían a los Centros de Referencia de los Virus Influenza; que en el caso de Costa Rica, al Centro de Enfermedades Infecciosas (CDC) en Atlanta, Estados Unidos, donde son analizados molecularmente. Dos veces al año, los 4 centros de referencia mundiales se reúnen y se escogen las cepas que serán incluidas en las vacunas de los hemisferios sur y norte. ${ }^{6}$

La producción de las vacunas contra el virus influenza dura de 9 a 10 meses, ya que se utiliza una cepa patrón y las cepas circulantes durante ese año. La cepa patrón tiene las características de crecer óptimamente en embriones de pollo y resultar inocua al ser humano. Se realizan infecciones mixtas en embriones de pollo para mezclarlas y obtener nuevas cepas que contengan los genes que codifican las proteínas internas de la cepa patrón, la cual dará a la nueva cepa las características de crecer en grandes cantidades y resultar inocua en el ser humano, y las glicoproteínas $\mathrm{H}$ y $\mathrm{N}$ de los virus circulantes que sirven de molde para inducir los anticuerpos protectores en los vacunados. ${ }^{23}$ Este proceso se debe hacer individualmente para cada cepa que contenga la vacuna. ${ }^{6}$

Las investigaciones desarrolladas desde el brote de H5N1 en Hong Kong, en 1997, han seguido la evolución de las cepas circulantes en Asia y se han escogido cepas que pueden servir como vacunas prepandémicas. ${ }^{24}$ En la actualidad hay varias que han sido probadas en voluntarios, demostrando que son poco inmunogénicas y que se deben aplicar más de una vez, lo cual las hace ineficientes. Con las vacunas estacionales se ha demostrado que la eficacia de una vacuna depende del grado de similitud antigénica que tenga con la cepa circulante. Por lo tanto, la idea de una vacuna prepandémica es producir anticuerpos en los vacunados para que adquieran algún gado de protección. El problema es producir grandes cantidades y que el virus de la próxima pandemia sea muy diferente antigénicamente, o que sea otro virus. ${ }^{25,26}$

La vacuna ideal sería aquella que se produzca a partir de la cepa pandémica, con el inconveniente de que la producción de la vacuna tomaría hasta 10 meses con la metodología tradicional, de forma que estaría lista para la segunda ola de la pandemia, si es que se presenta como en 1918-1919.7,8

Actualmente, varios laboratorios en el mundo están implementando la técnica de la genética reversa para lograr producir vacunas contra este virus en menos tiempo. Esta técnica consiste en hacer plásmidos, para lo cual cada segmento de ARN viral se convierte a ADN por medio de la transcriptasa reversa y se agregan a células cultivadas en el laboratorio para que sean instruidas por los plásmidos y produzcan el virus vacunal (Figura 1). ${ }^{27}$

Algunas de las ideas es tener listo el virus patrón con la escogencia correcta de las proteínas internas que le brinden las características de crecer óptimamente y con inocuidad para el ser humano, de manera que cuando aparezca el virus pandémico solo se deban clonar sus glicoproteínas. En el caso de la $\mathrm{H}$, se recomienda que se elimine el segmento del gen que puede brindarle al virus la posibilidad de ser sistémico. Uno de los problemas encontrados es que el virus vacunal obtenido por medio de genética reversa solo crece del $30 \%$ al $40 \%$ en embriones de pollo, en comparación con los virus estacionales, lo que hace que la producción de antígeno sea muy pobre y, por lo tanto, la vacuna sea menos eficaz. $^{28}$

Existe una capacidad limitada de producción de vacunas de influenza estacional (300 millones de dosis al año), la cual se vería en grandes problemas si hubiera además que producir muchas dosis de vacunas contra el H5N1. ${ }^{29}$ Según el comentario aparecido Stephenson y colaboradores, ${ }^{30} \mathrm{se}$ debería iniciar la producción de vacunas $\mathrm{H} 5 \mathrm{~N} 1$ aunque sean parcialmente protectoras, ya que los sistemas de modelaje sugieren que si se vacuna del $30 \%$ al $50 \%$ de la población, se logra detener la diseminación del virus. Este mismo comentario hace la observación de que teniendo suficiente del antiviral oseltamivir como para tratar del $20 \%$ al $25 \%$ de la población, podría reducir las admisiones hospitalarias en un $67 \%$, y las muertes en un 53\%. Obviamente, los países que no tienen capacidad de producir sus propias vacunas y antivirales se verán en grandes problemas y dependerán de la Organización Mundial de la Salud para suficientes con el fin de vacunar y tratar al personal que tendría que darle la cara a la pandemia.

Antivirales: Existen dos tipos de antivirales para los virus influenza. Los adamantadanos, como la adamantadina, que actúan sobre la proteína M2, previniendo la descapsidación del virus, estos solo son útiles sobre los virus tipo A, y se ha demostrado que los virus H5N1 son resistentes, por lo tanto, se ha descartado su utilización para la posible 
pandemia por este virus. El oseltamivir y el zanamivir interfirieren con el sitio enzimático de la neuraminidasa, inhibiendo así la liberación de los virus de las células. El oseltamivir es el antiviral que se recomienda, ya que es absorbido y metabolizado, y es capaz de llegar al sistema gastrointestinal y al sistema nervioso, donde el virus H5N1 causa patología. Se ha demostrado resistencia al oseltamivir, pero en un porcentaje mucho menor que la amandadina. ${ }^{31}$

El uso de antivirales contra el virus influenza se utiliza como profilaxis, por que se ha demostrado que protege contra la infección en un $70 \%$ a un $80 \%$ de las personas, reduce las complicaciones, y las hospitalizaciones, así como la mortalidad. ${ }^{31}$

\section{Sintomatología, patogénesis y virulencia}

La infección asintomática o leve por el virus H5N1 en humanos es posible, ya que los estudios de seroprevalencia así lo demuestran. ${ }^{32,33}$ En la infección sintomática, estos virus tienen la capacidad de afectar el sistema respiratorio superior e inferior, producir el síndrome de gastroenteritis aguda con diarrea, vómito y dolor abdominal, y también pueden producir encefalitis. ${ }^{14}$ Muchos de los pacientes que presentan neumonía progresan al síndrome de insuficiencia respiratoria o al síndrome de disfunción de múltiples órganos. ${ }^{14}$

Una vez que el virus entra a la célula, la síntesis de proteína celular se paraliza debido a la degradación de los mensajeros por la endonucleasa viral, lo que produce la pérdida de proteínas críticas que llevan a la muerte celular por necrosis. Se ha demostrado que la proteína no estructural (NS1) de los virus H5N1 tiene la capacidad de antagonizar el efecto antiviral del interferón y el factor de necrosis tumoral alfa (TNF-alfa) producidos durante la respuesta inmune innata en contra de la infección. ${ }^{34}$ Además, se ha demostrado in vitro que los H5N1 aislados de humanos son mucho más potentes que los virus $\mathrm{H} 1 \mathrm{~N} 1$ y los $\mathrm{H} 3 \mathrm{~N} 2$ en inducir citoquinas pro inflamación, ${ }^{35}$ lo que lleva a una tormenta de citoquinas y muerte celular. ${ }^{36}$ Estos mecanismos explican el edema alveolar, la hemorragia, la exudación alveolar con macrófagos CD68 y la infiltración interstidial con linfocitos CD3.

\section{La diseminación del virus pandémico}

Las aves migratorias han sido implicadas en la diseminación del H5N1 por el mundo, ya que se han relacionado las diferentes rutas de migración con aves muertas y positivas por el virus H5N1, pero también se han reportado brotes del virus en aves de corral lejos de las rutas migratorias. En este momento se considera que el motivo fundamental de la diseminación se debe al intercambio comercial y al transporte de aves vivas y carne de forma ilegal, entre los países asiáticos y europeos. ${ }^{37}$

\section{¿Por qué no ha ocurrido la pandemia?}

Las razones por las cuales no se ha iniciado la pandemia hasta el momento, son de diferente índole. El receptor celular que es reconocido por el receptor viral, la educación en el manejo de las aves domésticas, en el mecanismo de infección, en los métodos de higiene preventivos $\mathrm{y}$, sobre todo, la respuesta rápida que ha tenido un impacto positivo para la prevención de la diseminación de cepas peligrosas. ${ }^{5}$

El fenómeno de la gripe aviar surge por la interacción de factores sociales, culturales, económicos, ambientales, ecológicos, y por la interacción de muchas especies y hábitats, por lo tanto, se debe abordar de una forma integral.

\section{Preparación para la pandemia}

La Organización Mundial de la Salud (OMS) ${ }^{38}$ ha clasificado varias etapas para determinar el grado de peligrosidad de las cepas del virus influenza que circulan en los diferentes hospederos del virus. La etapa 00a es cuando no se detecta un subtipo de virus influenza nuevo y no existe indicación de actividad de influenza aviaria de alta patogenicidad en especies de animales susceptibles. La etapa $00 \mathrm{~b}$ es cuando no se detecta un subtipo de virus influenza nuevo pero se detecta actividad de influenza aviaria de alta patogenicidad en especies animales susceptibles. La 01 es cuando se aisla un subtipo nuevo de virus de un caso humano único, pero no se detecta transmisión de persona a persona. La etapa 02 es cuando son confirmadas dos o más infecciones humanas por el nuevo virus pero no se detecta transmisión de persona a persona. En la etapa 03 se confirma transmisión de persona a persona. La etapa 1.0 es el inicio de la pandemia y se confirma transmisión de persona a persona acentuada. En este momento estamos en la etapa 02, aunque existen reportes que confirman la transmisión de persona a persona, pero de forma restrictiva. ${ }^{39}$

En la página de Internet de la $\mathrm{OMS}^{38}$ se encuentran los manuales con todos los procedimientos que se deben seguir en caso de que ocurra la pandemia. La información ahí citada es específica para todo el personal que deberá atender la emergencia en los niveles comunitario y hospitalario. También se encontrarán los protocolos para el manejo de pacientes, su cuido y tratamiento.

El Ministerio de Salud de Costa Rica ha constituido una Comisión interinstitucional y multidisciplinaria que tiene como objetivo preparar al país ante la amenaza de la pandemia del virus de la gripe aviar. La Caja Costarricense de Seguro Social trabaja arduamente en la preparación de protocolos y abordajes preventivos y de contención ante la posibilidad del peligro.

¿Cuán preparado está el mundo para enfrentar esta nueva amenaza? Muchos expertos creen que se sabrá el día cuando se deba enfrentar el problema, pero se teme que el miedo en la población podría causar más daño que el mismo 
virus. Por esta razón, la OMS insiste en promover los mecanismos de prevención y, sobre todo, de educación, para que se retomen las prácticas saludables de higiene, como el lavado de manos, el uso de pañuelos de papel, entre otros.

El virus influenza no es predecible, puede mutar a ser menos virulento o dos cepas pueden encontrarse en una misma célula y producir un nuevo virus que sea el que adquiera las características biológicas que le den la capacidad de multiplicarse en el ser humano, transmitirse y producir una pandemia. Es por eso que la vigilancia epidemiológica de este virus es tan importante en el mundo entero, y Costa Rica no es la excepción. ${ }^{40}$

\section{Referencias}

1. Webster RG. Influenza: An Emerging Disease. Emerg Infect Dis 1998;4:1-7.

2. Murphy BR \& Webster RG.. Orthomyxovirus. En: Virology. Fields BN et al (ed). Lippincott-Raven Publishers. 1996. pp.1397-1445

3. Kuiken T, Holmes EC, McCauley J, Rimmelzwaan GF Williams C.S Grenfell B.T. Host species barriers to Influenza Virus Infections. Science 2006; 312:4-13.

4. Yamada Sh, Suzuki Y, Suzuqui T, Le M, Nidom ch, Sakai Y, et al. Haemagglutinin mutations responsable for the binding of $\mathrm{H} 5 \mathrm{~N} 1$ influenza A virases to human-type receptors. Nature. 2006; 444:378382.

5. Webster R. G. Peiris M, Chen H, Guan Y. H5N1 Outbreaks and Enzootic Influenza Emerg Infect Dis 2006;12:3-8.

6. Palese P. Making Better Influenza Virus Vaccines? Emerg Infect Dis 2006; 12:61-64.

7. Taubenberger JK \& Morens, DM. 1918 Influenza: the Mother of All Pandemics. Emerg Infect Dis 2006; 12: 1-12.

8. Johnson NP, Mueller J. Updating the accounts: global mortality of the 1918-1920 "Spanish" influenza pandemic. Bull Hist Med 2002; 76:105-15

9. Kobasa D, Takada A, Shinya K, Hatta M, Halfmann P, Theriault S, et al. Enhanced virulence of Influenza A viruses with the haemagglutinin of the 1918 pandemic virus. Nature 2004; 431:703-701.

10. Reid AH, Fanning TG, Hultin JV, Taubenberger JK. Origen and evolution of the 1918 "Spanish" influenza virus hemagglutinin gene. Proc Nalt Acad Sci USA 1999; 96:1651-56.

11. Kilbourne ED. Influenza Pandemics of the $20^{\text {th }}$ Century. Emerg Infect Dis. 2006;12:9-14

12. Dowdle WR. Influenza Pandemic Periodicity, Virus Recycling and the Art of Risk Assessment. Emerg Infect Dis 2006;12:34-39.

13. Karasin AI, Olsen CW, Anderson GA. Genetic characterization of an H1N2 influenza virus isolated from a pig in Indiana. J Clin Microbiol. 2000;38:2453-6.

14. Yeun KY, Wong SSY. Human Infection by avian influenza A H5N1. Hong Kong Med J. 2005;11:189-199.

15. Liu J, Xiao H, Lei F, Zhu Q, Qin K, Zang X-W et al. Highly Pathogenic H5N1! Influenza Virus Infection in Migratory Birds. 2005; Science 309:1206.

16. Webster R G. Wet markets- continuing source of severe acute respiratory syndrome and Influenza? Lancet. 2004;363:234

17. Halvorson S. Avian Influenza. Disponible en: www.cvm.umn.edu/ai old/home.html
18. Luke CJ \& Subbaroa K. Vaccines for Pandemic Influenza. Emerg Infect Dis 2006; 12:66-72.

19. Kuiken T, Rimmelzwaan G, van Riel D, van Amerongen G, Baars M, Fouchier R et al. Avian H5N1 influenza in cats. Science 2004;306: 241.

20. Shinyal K, Ebina M, Yamada Sh, Ono M, Kasai N, Kawaoka Y, et al. Avian flu: Influenza virus receptors in the human airway. Nature 2006; 440: 435 .

21. Olsen B, Munster VJ, Wallensten A, Waldenstrom J, Osterhaus ADME, Fouchier RAM. Global Patterns of Influenza A virus in Wild Birds. Science. 2006; 312:4-8.

22. Garcia-Sastre A. Antiviral Response in Pandemic Influenza Viruses. Emerg Infect Dis 2006;12:44-7.

23. Thomas PG, Keating R, Hulse-Post DJ, Doherty PC. Cell-Mediated Protection in Influenza Infection. Emerg Infect Dis. 2006;12:48-54.

24. Quirk M. H5N1 genes show avian origins and drifting. Emerg Infect Dis 2005; 11: 1510-21.

25. Stephenson I, Bugarini R. Nicholson KG, Podda a, Wood JM Zambon MC, Katz JM. Cross-Reactivity to highly Pathogenic Avian Influenza H5N1 Viruses after Vaccination with Nonadjuvant and MF59Adjuvantes Influenza A/Duck/Singapore/97 (H5N3) Vaccine: A Potential Priming Strategy. JID 2005;191:1210-5

26. Yang ZY, Wei ChJ, Kong WP, Wu L, Xu L Smith D.F. Nabel GJ. Immunization by Avian H5 Influenza Hemagglutinin Mutants with Altered Receptor Binding Specificity. Science 2007; 317:825-8.

27. Taubenberger JK, Reid A.H. \& Fanning TG. Capturing a Killer Flu virus. Scientific American. 2005. pp. 62-71.

28. Stephenson I, Gust I, Pervikov Y, Kieny MP. Development of vaccines against influenza H5. Lancet Infect Dis. 2006; 6:458-9.

29. Influenza pandemic preparation — much still to be done. Lancet Infect Dis 2006; 6: 315 .

30. Stephenson I, Gust I, Pervikov Y, Kieny MP. Development of vaccines against influenza H5. Lancet Infect Dis 2006; 6:458-9.

31. Gani, R, Hughes H, Fleming D, Griffin T, Medlock J, Leach S. Potential Impact of Antiviral Drug Use during Influenza Pandemic. Emerging Infectious Diseases 2006; 11:1-13.

32. Katz JM, Lim W, Bridges CB, et al. Antibody response in individuals infected with avian influenza A (H5N1) viruses and detection of antiH5 antibody among household and social contacts. J Infect Dis 1999;180:1763-70.

33. Buxton Briges C, Katz JM, Seto WH, et al. Risk of influenza A(H5N1) infection among health care workers exposed to patients with influenza A (H5N1), Hong Kong. J Infect Dis. 2000;181:344-8.

34. Seo SH, Hoffmann E, Webster RG. Lethal H5N1 influenza viruses escape host anti-viral cytokine responses. Nat Med 2002,8:950-4.

35. Cheung CY, Poon LL, Lau AS, Shortridge KF, Gordon S, Guan Y, et al. Induction of proinflammatory cytokines in human macrophages by influenza A (H5N1) viruses: a mechanism for the unusual severity of human disease? Lancet 2002; 360:1831-7.

36. Peiris JS, Yu WC, Leung CW, Cheung CY, Ng WF, Nicholls JM, et al. Re-emergence of fatal human influenza type A subtype H5N1 disease. Lancet 2004; 363:617-9.

37. Bonn D. Wild birds, poultry, and avian influenza. Lancet Infect Dis 2006;6:262

38. Secretaría de Salud. Acciones Básicas ante una Pandemia de Influenza. Boletín de Práctica Médica Efectiva. Diciembre 2006.

39. Yang Y, Halloran ME, Sugimoto J, Longini, Jr IM. Detecting human-to-human transmission of avian influenza A (H5N1). Disponible en: http://www.cdc.gov/EID/content/13/9/1348.htm>

40. Herrero, L. Alfaro, W. Virus Influenza circulantes en Costa Rica 1998 - 2001. ¿Cuándo vacunar? Acta Médica Pediátrica 16(3):111115,2002 . 